\title{
TOWARDS RECONSTRUCTING THE MEANING OF INHUMAN TREATMENT OR PUNISHMENT: A HUMAN CAPABILITY APPROACH
}

\author{
SONIA BOULOS 1
}

\begin{abstract}
The prohibition on "inhuman treatment" constitutes one of the central tenets of modern international human rights law. However, in the absence of any legislative definition of the term "inhuman", its interpretation becomes challenging. The aim of this article is to critically analyze the interpretation of the term "inhuman" in international human rights law and to suggest a new approach to defining it. The first part of the article highlights the failure of supra-national institutions to provide an independent definition for the term "inhuman", while mistakenly equating it to other forms of ill-treatment. The second part of the article introduces philosophical concepts necessary for reconstructing the conceptual independence of the term inhuman. It primarily focuses on "the capability approach" and the notion of "human functioning", as developed by Martha Nussbaum.
\end{abstract}

Keywords: inhuman treatment, capabilities approach, human functioning.

Summary: I. INTRODUCTION; II. INHUMAN TREATMENT IN THE JURISPRUDENCE OF SUPRA-NATIONAL INSTITUTIONS; III. TOWARDS UNFOLDING THE MEANING OF INHUMAN TREATMENT; IV. CONCLUSION.

\section{INTRODUCTION}

The prohibition on "inhuman" treatment is a central tenet of international human rights law. Article 5 of the Universal Declaration of Human Rights (UDHR) states "[n]o one shall be subjected to torture or to cruel, inhuman or degrading treatment or punishment." 2 Article 7 of the International Covenant on Civil and Political Rights (ICCPR) restates the same language. ${ }^{3}$ Article 16.1 of the Convention against Torture and other Cruel, Inhuman or Degrading Treatment or Punishment (CAT) states, “[e]ach State Party shall undertake to prevent in any territory under its jurisdiction other acts of cruel, inhuman or degrading treatment or punishment." ${ }^{4}$ On the regional level, the prohibition is found in Article 3 of the

1 Lecturer, Department of International Relations and Law, Universidad Antonio de Nebrija, Spain (sboulos@nebrija.es).

${ }^{2}$ G.A. Res. 217 (III) A, Universal Declaration of Human Rights (Dec. 10, 1948).

${ }^{3}$ International Covenant on Civil and Political Rights, Dec. 16, 1966, S. Exec. Doc. No. 95-209, 999 U.N.T.S. 171.

${ }^{4}$ Convention Against Torture and Other Cruel, Inhuman or Degrading Treatment or Punishment, Dec. 10, 1984, S. Treaty Doc. No. 100-20, 1465 U.N.T.S. 85. 
European Convention on Human Rights (ECHR), ${ }^{5}$ Article 5.2 of the American Convention on Human Rights (American Convention), ${ }^{6}$ and Article 5 of the African Charter on Human and Peoples' Rights (African charter). ${ }^{7}$

The prohibition on inhuman treatment also constitutes a central tenet of international criminal law. Inhuman treatment of civilians, ${ }^{8}$ prisoners of war, ${ }^{9}$ or of the wounded and the sick $^{10}$ constitutes a war crime and a grave breach of the Geneva Conventions (GCs).

However, in the absence of any legislative definition of term 'inhuman', its interpretation becomes challenging. As Jeremy Waldron puts it, "[e]ven with the best will in the world it is not easy to figure out what these provisions forbid." ${ }^{11}$ The aim of this article is twofold: First, the article criticizes the interpretation of the term "inhuman" by international human rights institutions; second, it introduces the "capability approach" as a conceptual framework to reconstruct its meaning.

The first part of the article highlights the reluctance of the supra-national human rights institutions to articulate an independent definition of the term "inhuman" and its other kin terms, i.e. “cruel” and “degrading”. Very often, these three prohibitions are treated as a singular prohibition referred to as "CIDT" with the purpose of distinguishing the latter from torture. This approach erroneously assumes that understanding "CIDT" requires a prior understanding of torture. In other words, this approach fails to recognize that each of these three prohibitions represents a distinct moral standard. Blurring the conceptual differences between the terms cruel, inhuman and degrading treatment has resulted in their gradual supplementation with long lists of purely descriptive rules announced by supra-national institutions, usually without sufficient legal reasoning.

While blurring the conceptual differences between the terms "cruel," "inhuman," and “degrading” has negative consequences for all three, the term "inhuman” remains the most

${ }^{5}$ Convention for the Protection of Human Rights and Fundamental Freedoms art. 3, Nov. 4, 1956, E.T.S. No. 5 .

${ }^{6}$ American Convention on Human Rights, Nov. 22, 1969, 1144 U.N.T.S. 123.

${ }^{7}$ Banjul Charter on Human and Peoples Rights, adopted June 27, 1981, 21 I.L.M. 58 (entered into force Oct. 21, 1986).

${ }^{8}$ See Geneva Convention Relative to the Protection of Civilian Persons in Time of War art. 147, Aug. 12, 1947, T.I.A.S. No. 3365, 75 U.N.T.S. 287.

${ }^{9}$ See Geneva Convention Relative to the Treatment of Prisoners of War art. 130, Aug. 12, 1949, T.I.A.S. No. 3364, 75 U.N.T.S. 135; Geneva Convention for the Amelioration of the Condition of the Wounded and Sick in Armed Forces in the Field art. 50, Aug. 12, 1949, T.I.A.S. No. 3363, 75 U.N.T.S. 31.

${ }^{10}$ See Geneva Convention for the Amelioration of the Condition of Wounded, Sick and Shipwrecked Members of Armed Forces at Sea art. 51, Aug. 12, 1949, T.I.A.S. No. 3362, 75 U.N.T.S. 85.

${ }^{11}$ Waldron, J., 2010. Torture, terror, and trade-offs: Philosophy for the White House. Oxford University Press, p. 279. 
impoverished. The term "cruel" can easily be linked to the clause on "cruel and unusual punishment," which appears in several constitutions that inherited it from The English Bill of Rights of 1689. ${ }^{12}$ This clause has been interpreted as prohibiting either excessive punishments or "barbarous" punishments. ${ }^{13}$ As for the term "degrading", it seems to reflect a dignatarian ideal. According to the European Court of Human Rights (ECtHR) degrading treatment is one that "humiliates or debases an individual, showing a lack of respect for, or diminishing, his or her human dignity." ${ }^{14}$ But when we turn to the term "inhuman," we are clueless on where to start our inquiry.

Following the Vienna Convention on the Law of Treaties (Vienna Convention) ${ }^{15}$, the second part of the article starts by unfolding the word-meaning of the term "inhuman" as a first step towards reconstructing its meaning. Regaining the conceptual independence of the term "inhuman" requires more than reflecting on its ordinary meaning, certain philosophical inquiries that link it the notion of "human" are in order. Therefore, the second part of the article introduces "the capability approach" and the notion of "human functioning" as key concepts for understanding and defining the term inhuman. The work of Martha Nussbaum is central for achieving this goal.

\section{INHUMAN TREATMENT IN THE JURISPRUDENCE OF SUPRA-NATIONAL INSTITUTIONS}

While CAT prohibits torture and what is commonly referred to as CIDT, it only defines the former. ${ }^{16}$ CAT's definition of torture has been used as a reference point in sketching the differences between torture and other forms of ill-treatment. According to what could be called as the "distinguishing approach," the terms cruel, inhuman and degrading should not treated as conceptually independent prohibitions, instead they are defined in

\footnotetext{
${ }^{12}$ See for example, U.S. Const. amend. VIII, which borrows the language of the English Bill of Rights almost word by word. Congressional Research Service Annotated Constitution: Eight Amendment, Legal Info. Inst., https://www.law.cornell.edu/anncon/html/amdt8_user.html (last visited April 10, 2019). Article 2(b) of the Canadian Bill of Rights of 1960 stipulates: "[N]o law of Canada shall be construed or applied so as to . . impose or authorize the imposition of cruel and unusual treatment or punishment." Canadian Bill of Rights, S.C. 1969, c 44, art. 2(b) (Can).

${ }^{13}$ For a comprehensive analysis of the history of the clause "cruel and unusual punishments," see Granucci, A.F., 1969. Nor cruel and unusual punishments inflicted: The original meaning. Calif. L. Rev., 57, p.839.

${ }^{14}$ Pretty v. United Kingdom, App. No. 2346/02 Eur. Ct. H.R. (Apr. 29, 2002) para. 52, HUDOC (Apr. 29, 2002); see also Yankov v. Bulgaria, App. No. 39084/97 Eur. Ct. H.R. (Dec. 11, 2003), para. 114; Kalashnikov v. Russia, App. No. 47095/99 Eur. Ct. H.R. (July 15, 2002), para. 101; Peers v. Greece, App. No. 28524/95 Eur. Ct. H.R. (Apr. 19, 2001) para. 75. In the aforementioned cases, the court stated that treatment "diminished the applicant's human dignity."

${ }^{15}$ Vienna Convention on the Law of Treaties art. 31, May 23, 1969, 1155 U.N.T.S. 331.

${ }^{16}$ Torture Convention, supra note 3, art. 1.
} 
relation to torture. The "distinguishing approach" is reflected in the formulation of Article 16 of the Torture Convention:

Each State Party shall undertake to prevent in any territory under its jurisdiction other acts of cruel, inhuman or degrading treatment or punishment which do not amount to torture as defined in article 1, when such acts are committed by or at the instigation of or with the consent or acquiescence of a public official or other person acting in an official capacity (emphasis added). ${ }^{17}$

According to this view, any attempt to understand CIDT requires a prior understanding of torture. The terms cruel, inhuman and degrading are treated as ancillary to the torture prohibition — “a fence around that wall”-, designed, as Jeremy Waldron puts it, to keep States "not just from crossing the torture threshold, but to keep them from even approaching it". ${ }^{18}$ For example, according to the Committee Against Torture, "the definitional threshold between ill-treatment and torture is often not clear. Experience demonstrates that the conditions that give rise to ill-treatment could lead to torture, therefore the measures required to prevent torture must be applied to prevent ill-treatment.”19

\section{A. Distinguishing Torture from CIDT}

To understand how the distinguishing approach works, we need to turn to the definition of torture in Article 1 of CAT:

Torture means any act by which severe pain or suffering, whether physical or mental, is intentionally inflicted on a person for such purposes as obtaining from him or a third person information or a confession, punishing him for an act he or a third person has committed or is suspected of having committed, or intimidating or coercing him or a third person, or for any reason based on discrimination of any kind, when such pain or suffering is inflicted by or at the instigation of or with the consent or acquiescence of a public official or other person acting in an official capacity. It does not include pain or suffering arising only from, inherent in or incidental to lawful sanctions.

Article 1 definition encompasses two elements that have been used to distinguish torture from “CIDT.” Those elements are: severity of pain and purpose.

\footnotetext{
${ }^{17}$ Id. art. 16.

${ }^{18}$ Supra-note 11 , at 277-78.

${ }^{19}$ U.N. Comm. Against Torture (CAT), Convention Against Torture and Other Cruel, Inhuman or Degrading Treatment or Punishment, General Comment 2: Implementation of Article 2 by State Parties, 3, U.N. Doc. (Nov. 23, 2007).
} 


\section{Severity of the Pain}

In torture the pain must be severe. Accordingly, the severity of the pain inflicted on the victim is what distinguishes torture from other forms of ill-treatment. ${ }^{20}$ This approach was adopted by the ECtHR in the case of Ireland v. United Kingdom. In this case, the Court found five interrogation techniques used in 1972 by the British security forces against IRA suspects to be inhuman and degrading, but not torture. ${ }^{21}$ The severity test was formulated as follows: “Admittedly the word 'torture' included in Article 3 of the Convention is not capable of an exact and comprehensive definition. It is undoubtedly an aggravated form of inhuman treatment causing intense physical and/or mental suffering." 22

Based on this test, the ECtHR concluded that the interrogation techniques used by the British security forces were only inhuman and degrading because they did not deserve the "special stigma" reserved to torture. ${ }^{23}$ The severity test was also adopted by the InterAmerican Court of Human Rights (IACtHR), ${ }^{24}$ and apparently by the African Commission of Human and People's Rights. ${ }^{25}$ While the ECtHR still maintains that the severity of the pain is the decisive criterion for distinguishing torture from other forms of ill-treatment, in recent cases it has incorporated "purpose" as an additional distinguishing criterion. For example, in Cirino and Renne v. Italy the ECtHR stated that in addition to the severity of the treatment, there is a purposive element to torture, as recognized in Article 1 of Torture Convention. $^{26}$

\footnotetext{
${ }^{20}$ This view was incorporated in the 1975 United Nations Declaration on the Protection of All Persons from Being Subjected to Torture and Other Cruel, Inhuman or Degrading Treatment or Punishment. G.A. Res. 3452 (XXX) (Dec. 9, 1975). According to article 1(2) of the declaration, "Torture constitutes an aggravated and deliberate form of cruel, inhuman or degrading treatment or punishment.” Id. annex, art. 1(2).

${ }^{21}$ Ireland v. United Kingdom, App. No. 5310/71 Eur. Ct. H.R., (Jan. 18, 1978) para. 246. The five techniques were hooding, wall standing, deprivation of food and drink, deprivation of sleep, and subjection to loud noise, in combination, but for less than twenty four hours.

${ }^{22}$ Id. para. 168.

${ }^{23}$ Id. para. 246.

${ }^{24}$ See Lizardo Cabrera v. Dominican Republic, Case 10.832, Inter-Am. Comm’n H.R., Report No. 35/96, OEA/Ser.L/V/II.98, doc. 6 rev., 82-83 (1998). See also Loayza-Tamayo v. Peru, Merits, para. 57 (Inter-Am. Ct. H.R. Sept. 17, 1997).

${ }^{25}$ See Int'l Pen ex rel. Saro-Wiwa v. Nigeria, Communications 137/94, 139/94, 154/96 and 161/97, African Commission on Human and Peoples' Rights [Afr. Comm'n H.P.R.] (Oct. 31, 1998). See also Huri-Laws v Nigeria (2000) AHRLR 273 (ACHPR 2000)(para 41).

${ }^{26}$ Cirino and Renne v. Italy, Applications nos. 2539/13 and 4705/13, Eur. Ct. H.R (26 October 2017).
} 


\section{Purpose}

Article 1 of the CAT requires that there be a purpose of a certain type for ill-treatment to amount to torture. The Article includes the following prohibited purposes: extracting a confession; obtaining information from the victim or a third person; punishing the victim; intimidating or coercing the victim; and any other purpose of a discriminatory nature. ${ }^{27}$ Article 1 also includes the term "for such purposes as," indicating that the list of purposes is non-exhaustive. The purpose criterion was partly adopted by (now defunct) European Commission in 1969 in a case brought against the Greek military government. ${ }^{28}$ In interpreting Article 3 of the ECHR, the European Commission took the view that: "The word "torture" is often used to describe inhuman treatment which has a purpose, such as the obtaining of information or confessions, or the infliction of punishment and it is generally an aggravated form of inhuman treatment.”29

Manfred Nowak, the former UN Special Rapporteur on Torture, claims that a thorough analysis of the travaux préparatoires of CAT and its systematic interpretation by the Committee against Torture lead to the conclusion that the decisive criteria for distinguishing torture from "CIDT" is the purpose of the conduct and the powerlessness of the victim. ${ }^{30}$

Nowak assumes that CAT distinguishes between situations under which the intentional infliction of pain by State agents is absolutely prohibited and other situations in which it is allowed within legal limits. ${ }^{31}$ The first type of situations is exemplified in Article 1 of CAT, which prohibits the use of force for the achievement of certain purposes (such as extracting confessions, intimidations, etc.). Article 1 focuses on powerless victims, i.e. victims who are under the direct control of the State. ${ }^{32}$

However, CAT does not prohibit in absolute terms the infliction of pain by state agents outside the context of Article 1. State agents are allowed to inflict pain to execute arrest warrants, to prevent crimes, to quiet riots, etc. In these scenarios the victim is not under the direct control of the State. The use of violence in such cases must meet the requirements

\footnotetext{
${ }^{27}$ See article 1 of CAT, supra-note 3.

${ }^{28}$ Denmark, Norway, Sweden and Netherlands v. Greece, App. Nos. 3321/67, 3322/67, 3323/67, 3344/67, 1969 Y.B. Eur. Conv. On H.R. 186 (Eur. Comm'n on H.R.).

${ }^{29}$ Id. at 186.

${ }^{30}$ Manfred Nowak (Rapporteur on Torture and Other Cruel, Inhuman or Degrading Treatment or Punishment), Study on the Phenomena of Torture, Cruel, Inhuman or Degrading Treatment or Punishment in the World, Including an Assessment of Conditions of Detention, para. 187, UN Doc. A/HRC/13/39/Add.5 (Feb. 5, 2010). ${ }^{31}$ Id.

${ }^{32}$ NowAK, M., MCARTHUR, E. AND BUCHINGER, K., 2008. THE UNITED NATIONS CONVENTION AGAINST TORTURE: A COMMENTARY . OXFORD: OXFORD UNIVERSITY PRESS, PP. 68-69.
} 
of necessity and proportionality. If the pain resulting from the use of violence violates these two principles, the act could be classified as "CIDT." 33

Nowak believes that the "powerlessness of the victim" explains the decision of the UN Committee against Torture in Hajrizi Dzemajl et. al. v. Yugoslavia. ${ }^{34}$ This case analyzed the legal implications of a racist pogrom against a Roma settlement causing intense fear and mental suffering for the victims, with the acquiescence of police officers. ${ }^{35}$ The Committee considered the claims of the applicants only under Article 16 of CAT and not under Article 1 perhaps because the victims of the pogrom were not under the direct control of the State. ${ }^{36}$

The purpose criterion was adopted by the drafters of the Rome Statute of the International Criminal Court (ICC) as part of the elements of the crimes under the jurisdiction of the ICC. What distinguishes both inhuman treatment and cruel treatment from torture as a war crime is the purpose criterion. ${ }^{37}$ However, both criteria "severity" and "purpose" are not sufficient to inform us about the conceptual differences between the terms collectively referred to as CIDT.

\section{B. Blurring the Differences between the Terms Cruel, Inhuman and Degrading}

In $\mathrm{T}$ v. UK the ECtHR attempted to sketch a definition for the term "inhuman treatment" as a treatment that was "premeditated", and one that was "applied for hours at a stretch and caused either actual bodily injury or intense physical and mental suffering." 38 This definition is a different articulation of the Court's previous rulings, according to which the distinction between torture and inhuman treatment "derives principally from a difference in the intensity of the suffering inflicted." 39 T v. UK further exacerbates the ambiguity of the term inhuman by introducing the word "premeditated" as opposed to "intentional" or "deliberate" infliction of pain. In recent years the ECtHR was willing to discuss in more depth the term degrading treatment by elaborating on its connection to human dignity. However, the ECtHR did not depart from its distinguishing approach in defining inhuman treatment. For example, In Cirino and Renne v. Italy the ECtHR stated that "it appears that it was the intention that the Convention should, by means of such a distinction, attach a

\footnotetext{
${ }^{33}$ Id.

34 Dzemajl v. Yugoslavia, Communication No. 161/2000, U.N. Comm. Against Torture, U.N. Doc. CAT/C/29/D/161/2000 (Nov. 21, 2002).

${ }^{35}$ Id. paras. 2.1-2.27.

${ }^{36}$ Id. para. 9.3.

${ }^{37}$ Int'l Criminal Court [ICC], Elements of Crimes, ICC-ASP/1/3 (Sept. 9, 2002). See Art. 8(2)(a)(ii)-1; Art. 8 (2) (a) (ii)-2, \& Art. 8 (2) (c) (i)-3.

38 T. v. United Kingdom, App. No. 24724/94 Eur. Ct. H.R. (Dec. 16, 1999), para. 69.

${ }^{39}$ See, e.g., Ireland v. United Kingdom, supra-note 20, para. 167.
} 
special stigma to deliberate inhuman treatment causing very serious and cruel suffering”. ${ }^{40}$ In Bouyid v. Belgium the Grand Chamber of the ECtHR declared that minor bodily injuries that do not involve serious physical or mental suffering cannot be described as inhuman or, a fortiori, torture, suggesting that the conceptual difference between torture and inhuman treatment should be reduced to quantitative difference in the pain inflicted on the victim. ${ }^{41}$ However, in Bouyid the Grand Chamber was willing to go at length in explaining the centrality of human dignity in understanding degrading treatment, citing almost twenty international and regional human right instruments that refer to the concept of human dignity. ${ }^{42}$ In this case the Grand Chamber had to decide whether slaps inflicted on a minor and an adult in police custody violate Article 3 of the ECHR. In determining the significance of a slap to the face, the Grand Chamber stated that "[a] slap to the face affects the part of the person's body which expresses his individuality, manifests his social identity and constitutes the centre of his senses ... which are used for communication with others" "The Grand Chamber further stated that "where an individual is deprived of his or her liberty ... any recourse to physical force which has not been made strictly necessary by the person's conduct diminishes human dignity and is in principle an infringement of the right set forth in Article 3".44 This ruling suggests that treating people as objects or as animals is degrading since such treatment is inconsistent with the demands of human dignity. At the same, the ECtHR does not attempt to identify the particular link between inhuman treatment and human dignity or the link between the former and any other philosophical concept.

The failure to identify clear conceptual differences between the terms "cruel," "inhuman" and "degrading" has resulted in approaching these prohibitions in a holistic fashion. Many times, supra-national institutions find a violation of the prohibition on CIDT without referring specifically to any of its components, or they find an ill-treatment to be "cruel and inhuman" or "cruel and degrading”. For example, in Linton v. Jamaica, the UN Human Rights Committee (HRC) concluded that "the mock execution set up by prison warders and the denial of adequate medical care after the injuries sustained in the aborted escape attempt. . . constitute cruel and inhuman treatment within the meaning of article 7" without making any distinctions between the terms. ${ }^{45}$

In Güler and Öngel v Turkey, the applicants participated in a demonstration in Istanbul against the NATO summit in the city. Many police officers were deployed to police the demonstration. After a statement was read out, the demonstrators started to disperse.

\footnotetext{
${ }^{40}$ Cirino and Renne v. Italy, Applications nos. 2539/13 and 4705/13, Eur. Ct. H.R. (26 October 2017 ), para 74.

${ }^{41}$ Bouyid v Belgium (Application no 23380/09), Eur. Ct. H.R. (28 September 2015) [Grand Chamber].

${ }^{42}$ Id.

43 Id, para 104.

${ }^{44}$ Id, para. 100.

${ }^{45}$ Linton v. Jamaica, Communication No. 255/1987, CCPR/C/46/D/255/1987 (Oct. 22, 1992), reprinted in Rep. of Human Rights Comm., para. 8.5, U.N. Doc. A/48/40 (Part II) (1993).
} 
However, a small group of protestors attacked the police with sticks and stones. In response, the police officers used tear gas and truncheons to disperse them. It was established that the applicants were arrested and beaten by the police even though they were not involved in the attacks. The ECtHR ruled that that the injuries sustained by the applicants amount to "inhuman and degrading" treatment without explaining why in this instance ill-treatment amounts to both prohibitions. ${ }^{46}$ In Ryabsev v. Russia, the applicant alleged that he had been ill-treated during and after his arrest in a sting operation for robbery. As a result of this illtreatment the applicant sustained injuries to his scalp and to his hand and suffered a broken nose and a broken finger. The ECtHR labeled this treatment as "inhuman and degrading". ${ }^{47}$

In Dushka v. Ukraine, the 17-year-old applicant had been arrested and interrogated in relation to a robbery without the presence of his parents or a lawyer. He alleged that that he had been ill-treated by the authorities to coerce him to confess. While in custody, the applicant sustained bruises, abrasions and other injuries on various parts of his body, which could have been inflicted by multiple impacts with blunt objects. The Court attached special importance to the fact that neither his parents nor a lawyer were informed of his arrest and labeled this treatment as contrary to Article 3 of the ECHR. ${ }^{48}$

Similar trends could be found in the jurisprudence of Inter-American institutions. In Maritza Urrutia v. Guatemala, the victim was detained arbitrarily. She was subjected to a series of ill-treatments. Those included covering her head with a hood, being handcuffed to a bed in a room with the light on and the radio at full volume, being subjected to prolonged interrogations, being threatened with death and threats to torture her and kill her family members and forcing her to film an incriminating video. The IACtHR labelled such treatment as "cruel and inhuman" without making any distinction. ${ }^{49}$ According to Pinzón et. al. in most cases the IACtHR declares that the treatment in question was contrary to Article 5(2) of the American Convention, "refraining from specifying the exact mode of treatment that has infringed the prohibition in that provision". 50

More puzzling is the labelling of a treatment as "inhuman or degrading." For example, in Van der Ven v. The Netherlands, the ECtHR stated that the combination of routine strip-searches and other stringent security measures implemented in a high security

\footnotetext{
${ }^{46}$ Güler and Öngel v Turkey, Applications nos. 29612/05 and 30668/05, Eur. Ct. H.R. (4 October 2011). 47 Ryabtsev v. Russia, Application no. 13642/06, Eur. Ct. H.R. (14 November 2013), see also McGlinchey v. United Kingdom, App. No. 50390/99 Eur. Ct. H.R. (Apr. 29, 2003); and D.G. v. Poland, no. 45705/07, Eur. Ct. H.R. (12 February 2013). 48 Dushka v. Ukraine, Application no. 29175/04, Eur. Ct. H.R. (3 February 2011).

${ }^{49}$ Urrutia v. Guatemala, Merits, Inter-Am. Ct. H.R. Nov. 27, 2003.

${ }^{50}$ Pinzón, D.R. et. al, 2014. The Prohibition of Torture and Ill-treatment in the Inter-American Human Rights System: A Handbook for Victims and Their Advocates (Vol. 2). OMCT Handbook Series Vol. 2, p. 107.
} 
prison amounted to inhuman or degrading treatment in breach of Article $3 .^{51}$ This suggests that inhuman and degrading are different terms even if the court is not willing to elaborate on this difference.

One would expect supra-national criminal tribunals to dwell more on meaning of these prohibitions. After all, the principle of legality requires criminal prohibitions to be formulated with enough precision to enable the individual to foresee the legal consequences of her actions. ${ }^{52}$ But criminal tribunals too fail to meet this expectation. The International Criminal Tribunal for the former Yugoslavia (ICTY) based its jurisprudence on the mistaken assumption that the terms cruel and inhuman are simply identical; furthermore, it opted for the "distinguishing approach" considering "severity" as the distinguishing criterion. In the Simic case, the ICTY noted that it is "generally accepted that cruel and inhumane treatment is a lesser included offence of torture, and that the latter is considered lex specialis in relation to cruel and inhumane treatment." 53

In the Delalić case, the ICTY defined inhuman treatment as "an intentional act or omission, that is an act which, judged objectively, is deliberate and not accidental, which causes serious mental or physical suffering or injury or constitutes a serious attack on human dignity." 54 In the same case, the ICTY declared that the offence of cruel treatment under common article 3 carries the exactly same meaning as inhuman treatment in the context of the "grave breaches" provisions of the GCs. ${ }^{55}$

The reluctance to distinguish between the various forms of ill-treatment seems to be deliberate. In its General Comment No. 20 the HRC deemed it unnecessary "to draw up a list of prohibited acts or to establish sharp distinctions between the different kinds of punishment or treatment; the distinctions depend on the nature, purpose and severity of the treatment applied." 56 However, given the special stigma attached to torture that HRC stated "it is appropriate to identify treatment as torture if the facts so warrant”. 57

\footnotetext{
${ }^{51}$ Van der Ven v. Netherlands, App. No. 50901/99 Eur. Ct. H.R. (Feb. 4, 2003).

${ }^{52}$ See for example Sunday Times v. United Kingdom, App. No. 6538/74 Eur. Ct. H.R. (Apr. 26, 1979).

${ }^{53}$ Prosecutor v. Simic, Case No. IT-95-9-T, Judgment, para. 71 (Int'l Crim. Trib. for the Former Yugoslavia Oct. 17, 2003).

${ }^{54}$ Prosecutor v. Delalić, Case No. IT-96-21-T, Judgment, para. 543 (Int’l Crim. Trib. for the Former Yugoslavia Nov. 16, 1998).

${ }^{55}$ Id. para. 443.

${ }^{56}$ Human Rights Comm., General Comment No. 20: Replaces General Comment 7 Concerning Prohibition of Torture and Cruel Treatment or Punishment (Art. 7), 44th Sess. (March 10, 1992), published in Compilation of General Comments and General Recommendations Adopted by Human Rights Treaty Bodies, at 31, para. 4, U.N. Doc. HRI/GEN/1/Rev.1 (July 29, 1994).

${ }^{57}$ HRC, Giri v. Nepal, Comm. No. 1761/2008, para. 7.5.
} 
The reluctance to provide independent definitions for such abstract terms has resulted in the adoption of long lists of descriptive rules, lacking a clear conceptual thread linking them to the terms referred to as CIDT. ${ }^{58}$ For example, in its Concluding Observation on the United States, the Committee Against Torture noted that interrogation techniques involving sexual humiliation, "water boarding", "short shackling" and the use of dogs to induce fear, constitute torture or CIDT. ${ }^{59}$ In reviewing periodic reports by other State parties, the Committee against Torture expressed its concern over: flogging and amputation of limbs; ${ }^{60}$ low minimum age of criminal responsibility and detention of child offenders as young as seven years in specialized hospitals or social protection institutions; ${ }^{61}$ long term detention of asylum seekers while their asylum claims are considered; ${ }^{62}$ detention in a cell for twenty-two hours a day without meaningful activities to occupy the prisoner's time; ${ }^{63}$ non-segregation of juvenile and adult prisoners, and non-segregation of male and female prisoners; ${ }^{64}$ incidents of bullying which cause self-harm and suicide in the armed forces; ${ }^{65}$ inappropriate use of chemical, irritant, incapacitating and mechanical weapons by law enforcement authorities in the context of crowd control; ${ }^{66}$ reprisals, intimidation and threats against persons reporting acts of torture or ill-treatment; ${ }^{67}$ prisoners having to pay for a portion of the expenses related

\footnotetext{
${ }^{58} \mathrm{Id}$, see also Waldron, supra-note 10, at 276-319.

${ }^{59}$ Consideration of Reports Submitted by States Parties Under Article 19 of the Convention, Concluding Observations and Recommendations of the Committee Against Torture, United States of America, para. 24, U.N. Doc. CAT/C/USA/CO/2 (July 15, 2006).

${ }^{60}$ Consideration of Reports Submitted by States Parties Under Article 19 of the Convention, Concluding Observations and Recommendations of the Committee against Torture, Yemen, para. 6, U.N. Doc. CAT/C/CR/31/4 (Feb. 5 2004).

${ }^{61}$ Id.

${ }^{62}$ Consideration of Reports Submitted by States Parties Under Article 19 of the Convention, Concluding Observations and Recommendations of the Committee Against Torture, Latvia, para. 6, UN Doc. CAT/C/CR/31/3 (Feb. 5 2004).

${ }^{63}$ Consideration of Reports Submitted by States Parties Under Article 19 of the Convention, Concluding Observations and Recommendations of the Committee Against Torture, Croatia, para. 8, U.N. Doc. CAT/C/CR/32/3 (June 11, 2004).

${ }^{64}$ Consideration of Reports Submitted by States Parties Under Article 19 of the Convention, Concluding Observations and Recommendations of the Committee Against Torture, Bosnia and Herzegovina, para. 14, U.N. Doc. CAT/C/BIH/CO/1 (Dec. 15, 2005).

${ }^{65}$ Consideration of Reports Submitted by States Parties Under Article 19 of the Convention, Concluding Observations and Recommendations of the Committee Against Torture, United Kingdom of Great Britain and Northern Ireland, Crown Dependencies and Overseas Territories, para. 4, U.N. Doc. CAT/C/CR/33/3 (Dec. 10, 2004).

${ }^{66}$ Consideration of Reports Submitted by States Parties Under Article 19 of the Convention, Concluding Observations and Recommendations of the Committee Against Torture, Canada, para. 4, UN Doc. CAT/C/CR/34/CAN (July 7, 2005).

${ }^{67}$ Consideration of Reports Submitted by States Parties Under Article 19 of the Convention, Concluding Observations and Recommendations of the Committee Against Torture, Argentina, para. 6, U.N. Doc. CAT/C/CR/33/1 (Nov. 10, 2004).
} 
to their imprisonment; ${ }^{68}$ incidents of uninformed and involuntary sterilizations of Roma women; ${ }^{69}$ the wearing of hoods or masks by officers effecting a forced deportation; ${ }^{70}$ the use of electro-shock stun belts and restraint chairs as methods of constraint; ${ }^{71}$ incommunicado detention of up to five days or longer; ${ }^{72}$ prolonged solitary confinement as a measure of retribution in prisons. ${ }^{73}$ However, as mentioned earlier, the adoption of such narrowly defined rules lacks any conceptual inquiries that link all rules to the prohibitions they are derived from.

\section{The Development of Jurisprudence that Lacks Sufficient Reasoning}

The interpretative approach adopted by supra-national institutions has led to the emergence of jurisprudence that suffers from the absence of sufficient legal reasoning. Cassese argues that the case law of the ECtHR on the interpretation of "inhuman and degrading treatment” needs to be strengthened by avoiding making decisions that offer no substantial reasoning. ${ }^{74}$ Waldron points out that in its jurisprudence the ECtHR has established a set of principles, presumptions ${ }^{75}$ and benchmarks ${ }^{76}$ for identifying a breach of article 3 of the ECHR. ${ }^{77}$ The principles are usually repeated in most cases dealing with article

${ }^{68}$ Consideration of Reports Submitted by States Parties Under Article 19 of the Convention, Concluding Observations and Recommendations of the Committee Against Torture, Czech Republic, para. 5, U.N. Doc. CAT/C/CR/32/2 (June 3, 2004).

${ }^{69}$ Id.

${ }^{70}$ Consideration of Reports Submitted by States Parties Under Article 19 of the Convention, Concluding Observations and Recommendations of the Committee Against Torture, Switzerland, para. 4, U.N. Doc. CAT/C/CR/34/CHE (June 21, 2005).

${ }^{71}$ Supra-note 58 , para. 35.

${ }^{72}$ Consideration of Reports Submitted by States Parties Under Article 19 of the Convention, Concluding Observations and Recommendations of the Committee Against Torture, Spain, para. 61, U.N. Doc. A/58/44 (2003); Consideration of Reports Submitted by States Parties Under Article 19 of the Convention, Concluding Observations and Recommendations of the Committee Against Torture, Russian Federation, para. 42, UN Doc. A/52/44 (1997).

73 Supra- note 58, para. 36.

${ }^{74}$ Cassese, A., 2008. The human dimension of international law: selected papers of Antonio Cassese. Oxford University Press, p. 329.

${ }^{75}$ An example of a presumption is the following:

[W]here an individual is taken into custody in good health but is found to be injured by the time of release, it is incumbent on the State to provide a plausible explanation of how those injuries were caused and to produce evidence casting doubt on the victim's allegations, particularly if those allegations were corroborated by medical reports, failing which a clear issue arises under Article 3 of the Convention.

See Yavuz v. Turkey, App. No. 67137/01 Eur. Ct. H.R., (Jan. 10, 2006) para. 38.

${ }^{76}$ Benchmarks usually refer to those set by other regional agencies, such as the European Committee for the Prevention of Torture and Inhuman or Degrading Treatment or Punishment. These benchmarks are adopted as guidelines by the ECtHR, and they usually focus on physical conditions of prison cells, see supra-note 11.

77 Supra-note 11, at 279. 
3 including, for example, that ill-treatment must attain a minimal level of severity to find a violation of article 3, and that severity is a relative concept depending on other factors such as age, sex and health. However, Waldron highlights the following:

No one spends much time reflecting on the meaning of the predicates that are incorporated in the Article 3 standard [...] The Court simply announces its finding that certain practices are inhuman or degrading while others are not. Or announces a principle that it is going to use in determining what is degrading or what is inhuman. ${ }^{78}$

The reluctance of human rights institutions to engage in a thoughtful reflection on the meaning of each of these prohibitions, referred to as CIDT (especially the terms cruel and inhuman) could be attributed to two factors. First, it seems that supra-national institutions assume that defining these prohibitions would make them less flexible and would limit their scope. While this concern is legitimate, it erroneously assumes that defining such terms from would strip them from their evaluate power by converting them to largely descriptive rules. This approach does not assume that a middle ground is indeed possible. Supra-national institutions can move from highly abstract language, such as the term inhuman treatment, to more precise definitions that still embody evaluative elements. This would guarantee the flexibility needed for an effective protection against ill-treatment; at the same time, it would facilitate the development of a coherent body of jurisprudence in applying such prohibitions.

The immediate move from abstract norms to purely descriptive subsidiary rules without providing an intermediary definition is a recipe for arbitrariness. In his capacity as an independent expert of the United Nations, Philip Alston warned about the growing inconsistencies in the evolving jurisprudence on the interpretation of the central human rights instruments. ${ }^{79} \mathrm{He}$ attributes such inconsistencies to the following factors: the recent proliferation of human rights standards; the increasing range and depth of the activities of the policy-making organs; and the expanding number of treaty bodies. Alston further warned that such inconsistencies could create confusion as to the "correct" interpretation of a given norm. This would result in "the undermining of the credibility of one or more of the treaty bodies and eventually a threat to the integrity of the treaty system." ${ }^{80}$ Beyond the ratification of international and regional human rights treaties, many States, mainly former British colonies in Africa and Commonwealth countries in Asia, the Caribbean, and the Pacific, wrote international human rights norms into their Bill of Rights. Long ago Lillich pointed out that reference to international human rights norms is becoming a frequent factor in

\footnotetext{
${ }^{78}$ Id. at 287.

${ }^{79}$ World Conference on Human Rights, Interim Report of Study on Enhancing the Long-Term Effectiveness of the United Nations Treaty Régime, para. 238, U.N. Doc. A/CONF.157/PC/62/Add.11/Rev.1, annex (Apr. 22, 1993).

${ }^{80}$ Id.
} 
constitutional decision making on a global scale. Judges at the domestic level look to international and regional instruments and the decisions of committees, courts and commissions interpreting them. ${ }^{81}$ In this complex reality maintaining a normative consistency becomes more necessary and more challenging.

While the prohibitions referred to as CIDT are primarily associated with deprivation of liberty, they have been applied to other spheres including racial discrimination, ${ }^{82}$ house demolitions, ${ }^{83}$ and possibly to the failure to recognize sex change. ${ }^{84}$ Cassese argued that such prohibitions should be utilized by the ECtHR to address severe violations of social and economic rights so they can constitute a bridge between civil and political rights and the broad field of social and economic rights. ${ }^{85}$ Given the ambiguity of such terms and the wide scope of their application, they become susceptible to incoherent instantiations. A list of descriptive rules can never provide meaningful guidance for domestic courts when confronted with a new practice that does not resemble any of the prohibitions on the list. ${ }^{86}$ This could lead to the emergence of contradictory case-law where the same practice is approved in one jurisdiction but outlawed in another. To avoid such a gloomy development, supra-national institutions must engage methodologically in conceptual arguments on the meaning of these prohibition that could serve as guiding principles in applying them coherently.

The second factor that could explain the reluctance of supra-national institutions to define these prohibitions is the simple fact that the latter are hard to define. Waldron distinguishes between three different types of language indeterminacy: ambiguity, vagueness, and contestability. ${ }^{87} \mathrm{He}$ argues that the terms “cruel," "inhuman” and "degrading” are all contestable. ${ }^{88}$ A phrase becomes contestable "when it is clear that it embodies a normative standard, but different users disagree about the detailed contents of that normative standard." ${ }^{89}$ For example, the Eighth Amendment of the United States Constitution, which prohibits cruel and unusual punishments, is a contestable standard. According to Waldron, we all agree that punishments are inherently unpleasant; however, we tend to disagree on

${ }^{81}$ Lillich, R.B., 1995. Harmonizing Human Rights Law Nationally and Internationally: The Death Row Phenomenom as a Case Study. . Louis ULJ, 40, p.699

${ }^{82}$ See, e.g., Cyprus v. Turkey, App. No. 25781/94 Eur. Ct. H.R., (May 10, 2001).

${ }^{83}$ See, e.g., Dzemajl v. Yugoslavia, supra-note 33.

${ }^{84}$ See X v. Federal Republic of Germany, App., No. 8041/77 Eur. Ct. H.R., (Dec. 15, 1977), where the European Commission on Human Rights declared admissible an application alleging a violation of Article 3 of the ECHR due to the failure of the respondent State to recognize the sex change of the applicant.

${ }^{85}$ Cassese, A., 1991. Can the Notion of Inhuman and Degrading Treatment be applied to Socio-economic Conditions. Eur. J. Int'l L., 2, p.141.

${ }^{86}$ Supra-note 11, at 289.

${ }^{87}$ Waldron, J., 1994. Vagueness in law and language: Some philosophical issues. Cal L. Rev., 82, p.509.

${ }^{88}$ Supra-note 10.

${ }^{89}$ Supra-note 86. 
how harsh punishments should be. But the term "cruel" is contestable because we also disagree on "whether cruelty is simply a matter of the intensity of the suffering, or whether it also refers to the malice, inhumanity, or disrespect with which the suffering was inflicted". ${ }^{90}$ Still, Waldron refuses to dismiss such prohibitions altogether. He rightly claims that many cases involving ill-treatment can be clearly classified as cruel. For example, no one doubts that burning people alive is a cruel, even though we might disagree on whether other methods of execution fall under this category. ${ }^{91}$ In Xuncax v. Gramajo, a United States District Court followed this approach. While the Court recognized that the prohibition on CIDT poses more complex definitional problems compared to torture, it emphasized that "[i]t is not necessary that every aspect of what might comprise a standard such as 'cruel, inhuman or degrading treatment' be fully defined and universally agreed upon before a given action meriting the label is clearly proscribed under international law."92

On the face of it, the indeterminacy of the term inhuman seems inconsistent with the principle of the rule of law. While its meaning and scope are controversial, the law's predictability and the law's ability to guide human behavior run as a common thread in the writings of theorists who have explored the concept of the rule of law. ${ }^{93}$ In his famous work “The Morality of Law" Lon Fuller claims that the inner morality of the law requires making rules coherent, clear, and practicable. The failure to do so amounts to failure in creating and maintaining a legal system. ${ }^{94}$ The clarity of the law is one of the most essential ingredients of legality. ${ }^{95}$ However, no conception of the rule of law can deny that in certain cases the highest degree of precision is impossible or even undesirable. Fuller acknowledges that we can never be "more exact than the nature of the subject matter with which we are dealing with admits. A specious clarity can be more damaging that an honest openended vagueness". ${ }^{96}$ When the provisions of the first international bill of rights were debated by the newly established United Nations, some states objected the inclusion of vague terminology such as "inhuman" in a legally binding treaty. In response to such criticism, Charles Malik, the Rapporteur of the drafting committee of the UDHR emphasized that given the unprecedented and shocking atrocities committed by the Nazis, it was better to run the risk of being vague than of being too particular in condemning such acts. ${ }^{97} \mathrm{~A}$ similar position is found in the Commentary on Common Art. 3 of the Geneva Conventions. The Commentary

\footnotetext{
${ }^{90}$ Id. at 528.

91 Supra-note 10 , at 535.

92 Xuncax v. Gramajo, 886 F. Supp. 162, 186 (D. Mass. 1995), at 187.

${ }^{93}$ See Hayek, F.A., 2006. The Road to Serfdom (Routledge Classics); Fuller, L.L., 1969. The morality of law (Vol. 152). Yale University Press; Finnis, J., 2011. Natural law and natural rights. Oxford University Press and; Waldron, J., The Rule of International Law' (2006). Harvard Journal of Law and Public Policy, 30 , p.15.

${ }^{94}$ L. Fuller, id.

${ }^{95}$ Id.

${ }^{96}$ Id, at 64.

${ }^{97}$ UN Doc. E/CN.4.AC.1.SR.23, p. 3.
} 
stipulates "one would never be able to catch up with the imagination of future torturers who wished to satisfy their bestial instincts; and the more specific and complete a list tries to be, the more restrictive it becomes". ${ }^{98}$ While the use of abstract language for prohibiting different forms of ill-treatment could be reconciled with the rule of the law, there is another aspect of the rule of law that comes into play in interpreting and applying such prohibitions.

Waldron points out that a separate current of thought in the rule of law tradition puts an emphasis on its procedural aspects. According to this view, the rule of law is not just about general rules, it is also about their impartial administration. The procedural side of the rule of law requires public institutions to sponsor and facilitate reasoned arguments in human affairs, and to allow people to have a say in confronting power. ${ }^{99}$ The procedural aspect of the rule of law values opportunities for active engagement in the administration of public affairs. When referring to legal norms Waldron states: "We don't just obey them or apply the sanction that they ordain; we argue over them adversarially, we use our sense of what is at stake in their application to license a continual process of argument back and forth, and we engaged in elaborate interpretive exercises about what it means to apply them faithfully as a system to cases that come before us". ${ }^{100}$ Elsewhere, Waldron states that "a philosophy of law would still be impoverished if it paid no attention to the defining role of law's aspiration to coherence among the norms that it contains and to the forms of reasoned argumentation that are involved both in maintaining that consistency and in bringing it to bear in the application of norms to particular cases". ${ }^{101}$ Brugger distinguishes between legal coherency and ethical coherency. Legal coherence entails that all provisions of the law, its purposes, principles and rules form a bond of unity. As a minimum, provisions of law should avoid contradiction. ${ }^{102}$ Ethical coherence requires a convincing or at least plausible interpretation of the social and political values that are referred to in legal provisions. ${ }^{103}$ Any legal interpretation must take both the law and the real world seriously, because a judgment that does not make sense in the real world we live in is an unsound judgment. ${ }^{104}$ According to Brugger, a persuasive interpretation "should strive to integrate the ideals of systemic consistency, social congruence, and stability of doctrine over time”. ${ }^{105}$

\footnotetext{
${ }^{98}$ Pictet, J. ed., 1952. The Geneva Conventions of 12 August 1949: Geneva convention for the amelioration of the condition of the wounded and sick in armed forces in the field (Vol. 1). International Committee of the Red Cross.

${ }^{99}$ Waldron, J., The Concept and the Rule of Law” (2008) 43. Ga L Rev, 1, p.1.

${ }^{100}$ Waldron, J., 2011. The rule of law and the importance of procedure. Nomos, 50, pp.3-31, p. 20

${ }^{101}$ Supra-note 98, p. 61.

${ }^{102}$ Brugger, W., 1994. Legal interpretation, schools of jurisprudence, and anthropology: Some remarks from a German point of view. Am. J. Comp. L., 42, p.395.

103 Id, at 413.

${ }^{104}$ Id.

${ }^{105}$ Id, at 414 .
} 
Applied to the context of CIDT, the immediate move from abstract language to purely descriptive rules impedes us from reflecting on the moral principles embodied in these prohibitions, and prevents us from augmenting on their relevance to the world we live in. Waldron rightly claims that an exclusive focus on subsidiary rules diminishes the moral arguments embodied in these prohibitions. ${ }^{106}$ Furthermore, this approach is inconsistent with the notion of ethical coherence too. With time, and with the expansion of the lists of subsidiary rules, every objectionable treatment could become inhuman, even if in ordinary life such treatment is not perceived as sufficiently grave to be labeled inhuman. This would diminish even further the moral authority of this term, which was incorporated into international human rights instruments as a response to gross violations of human rights.

\section{TOWARDS UNFOLdING THE MEANING OF INHUMAN TREATMENT}

According to Article 31(1) of the Vienna Convention: “[a] treaty shall be interpreted in good faith in accordance with the ordinary meaning to be given to the terms of the treaty in their context and in the light of its object and purpose." 107 Courts had resorted to dictionaries when this methodology was found useful for interpreting legal norms. ${ }^{108}$

Unfolding the word-meaning is only the first step in the quest for moral and legal meanings. The words themselves can help us identify the moral principles and the distinct evaluations that are at stake.

\section{A. Inhuman Treatment: An Introduction}

The Oxford English Dictionary (OED) online defines “inhuman” when applied to persons as "[n]ot having the qualities proper or natural to a human being; esp. destitute of natural kindness or pity; brutal, unfeeling, cruel." ${ }^{109}$ When applied to actions or conduct, inhuman means “[b]rutal, savage, barbarous, cruel.” Inhuman also means "[n]ot pertaining to or in accordance with what is human, in form, nature, intelligence, etc". This definition encompasses both an agent-oriented approach and a victim-oriented approach. ${ }^{110}$ The former focuses on the mental disposition of the agent inflicting inhuman treatment, while the latter focuses on what objectively happens to the victim. ${ }^{111}$

\footnotetext{
106 Supra-note 11, at 289.

107 Supra-note 14.

${ }^{108}$ See for example the Delalić case, supra-note 53, para. 518.

109 OED Online. March 2017. Oxford University.

110 Supra-note 10 at 303.

${ }^{111} \mathrm{Id}$.
} 


\section{The Agent-Oriented Approach}

An example of the agent-oriented understanding of the term inhuman is found in the Dance of the Devils Case, where the German Federal Constitutional Court interpreted inhuman as follows:

The offense element "inhuman" is supposed to express the idea that action is taken with a cast of mind which shows contempt for humanity, or is inconsiderate, callous or merciless... perhaps because it is gives the perpetrator satisfaction to mistreat or kill human beings completely unscrupulously and in cold blood. ${ }^{112}$

The separate opinion of Judge Fitzmaurice in Ireland v. UK provides another example:

[T]he concept of "inhuman treatment" should be confined to kinds of treatment that. . . no member of the human species ought to inflict on another, or could so inflict without doing grave violence to the human, as opposed to animal, element in his or her make-up. ${ }^{113}$

Fitzmaurice's approach reflects both agent-oriented approach and victim-oriented approach because it refers to the moral defect in the person inflicting the ill-treatment and to treatment that cannot be inflicted a human being (as opposed to cruelty to other creatures). ${ }^{114}$

\section{The Victim-Oriented Approach}

The victim-oriented approach seems more appropriate for defining inhuman treatment since the prohibition on cruel treatment is a better candidate for capturing the moral defect in the person inflicting the ill-treatment. ${ }^{115}$ The OED defines cruelty as, inter alia, "disposition to inflict suffering; delight in or indifference to the pain or misery of others; mercilessness”.

But how can we strip humans from their humanity? Hannah Arendt suggests that we strip people from their humanity by diminishing their capacity for spontaneous action. ${ }^{116} \mathrm{In}$

\footnotetext{
112 BVerfGE 87, 209 (October 29, 1992), as quoted in Dubber, M. and Hörnle, T., 2014. Criminal law: a comparative approach. Oxford University Press, p. 92.

${ }^{113}$ Supra-note 20, para. 26.

${ }^{114}$ Supra-note 11, at 305.

${ }^{115}$ For on the meaning of cruel treatment see supra-note 12.

${ }^{116}$ Arendt, H., Jaspers, K., Köhler, L. and Saner, H., 1992. Hannah Arendt/Karl Jaspers Correspondence, 19261969.
} 
describing radical evil, Arendt suggests that it is about the destruction of the capacities of humans as we know them. ${ }^{117}$ Suffering "is not the issue, nor the number of victims. Human nature as such is at stake." 118 Suffering is just an instrument for controlling the unpredictability which forms part of inmates' nature. ${ }^{119}$

Waldron defines "inhuman treatment" as "treatment which cannot be endured in a way that enables the person suffering it to continue the basic elements of human functioning." 120 Those include self-control, rational thought, care of self, the ability to interact with others, the need to sleep, to defecate or urinate, the need for daylight and exercise and so on. ${ }^{121}$ Here too the term 'inhuman' plays a normative role; it represents a contestable standard on what we consider as an elementary human functioning. ${ }^{122}$ However, Waldron does not elaborate further on the notion of basic elements of human functioning. He immediately suggests a list of such functionings. In the absence of minimal inquiry into the notion of human functioning, his project too faces the risk of being converted into a list of subsidiary rules.

\section{B. Human Well Being, Human Functioning and the Capability Approach}

The notion of human functioning is discussed extensively in the literature on the "Capabilities Approach"; some leading scholars such as Martha Nussbaum have attempted to articulate a list of basic human capabilities. ${ }^{123}$ The notion of human capabilities was first introduced by Amartya Sen, who provided its framework largely in the 1980s and 1990s. ${ }^{124}$ The capability approach initially emerged in the field of development. Robeyns provides a good summary of Sen's work: well-being and development should be conceptualized in terms of people's capabilities to function, in other words, their effective opportunities to pursue the actions and the activities that they want to engage in and to be whoever they want to be. ${ }^{125}$ Those functionings constitute what makes a life valuable. Functionings include working, being healthy, being literate, being part of a community, resting, being respected, and so forth. The gap between achieved functionings and human capabilities is a gap between the realized and the effectively possible, or between achievements and larger freedoms. The ultimate goal must be enhancing human capabilities, so people can lead a life that they truly

\footnotetext{
117 Auestad, L., 2005. Plurality and human dignity. Nordisk Tidsskrift for Menneskerettigheter, 23, p.261.

118 Arendt, H., 1973. The origins of totalitarianism (Vol. 244). Houghton Mifflin Harcourt, p. 458-59.

119 Supra-note 116, at 264.

120 Supra-note 11.

121 Id

122 Id.

123 Nussbaum, infra-note 135.

124 Sen, A., 2014. Development as freedom (1999). Roberts, JT, Hite, AB \& Chorev, N. The Globalization and Development Reader: Perspectives on Development and Global Change, 2, pp.525-547.

125 Ingrid Robeyns, The Capability Approach: A Theoretical Survey, 6 Journal of Human Development 93 (2005).
} 
desire. Once they possess these capabilities, they can choose to act on them in line with their own conception of the good life. ${ }^{126}$ According to Nussbaum, in the capabilities approach we focus on "a variety of functions that would seem to be of central importance to a human life." ${ }^{127}$ Nussbaum's views on capabilities are intimately tied to the notion of human dignity, and to the conception of a life that is worth living. ${ }^{128}$ According to Nussbaum, dignity "is closely related to the idea of active striving". ${ }^{129}$ It is an innate potential that deserves to be developed; it is about the existence of minimal agency. ${ }^{130}$ Even The decay of the body cannot take away active striving and minimal agency. Unlike the Kantian approach to human dignity, which bases human dignity entirely on rationality, Nussbaum perceives human beings as inherently animals and a as members of the natural world. Therefore, human dignity is marked by "sentience, emotion, affection, physical health, and appetite as well as ... rationality". ${ }^{131}$ Even human beings with severe cognitive disabilities or those who possess a minimal level of sentience and striving are full equals in human dignity, and an attack on any of the elements that mark human dignity is an assault on human dignity. ${ }^{132}$ Kittay criticizes the concept of dignity adopted by Nussbaum since it weakens the attribution of dignity to people in a permanent vegetative condition, or to anencephalic infants. Kittay suggests base human dignity not on minimal agency but on the capacity to care and be cared for. ${ }^{133}$

Nussbaum's articulation of the capability approach is based on Aristotelian philosophy, i.e. on an essentialist view of human life as encompassing central defining features of basic human needs and human functions. ${ }^{134}$ The idea behind Nussbaum's approach to capabilities is twofold. First, there are certain functions that are essential in human life. Having these capabilities makes life worthy of the dignity of the human being. Second, humans must be able to perform these functions in a truly human way, as opposed to animal way. ${ }^{135}$

Nussbaum identifies ten basic human capabilities which constitute central requirements of a life with dignity. Nussbaum emphasizes: “[w]e are not pretending to

\footnotetext{
${ }^{126}$ Id.

${ }^{127}$ Nussbaum, M.C., 1997. Capabilities and human rights. Fordham L. Rev., 66, p.273.

128 Nussbaum, M., 2000. Women's capabilities and social justice. Journal of human development, 1(2), pp.219247.

${ }^{129}$ Nussbaum, M.C., 2011. Creating capabilities. Harvard University Press., p. 31.

130 Id.

${ }^{131}$ Dixon, R. and Nussbaum, M.C., 2011. Abortion, dignity and a capabilities approach, p. 5.

132 Id.

${ }^{133}$ Kittay, E. (2005). Equality, dignity and disability. In M. A. Waldron \& F. Lyons (Eds.), Perspectives on equality: Thesecond Seamus Heaney lectures (pp. 95-122). Dublin: Lifey

134 Nussbaum, M.C., 1992. Human functioning and social justice: In defense of Aristotelian essentialism. Political theory, 20(2), pp.202-246.

134 Nussbaum, M., 2000. Women's capabilities and social justice. Journal of human development, 1(2), pp.219247.
} 
discover some value-neutral facts about ourselves, independently of all evaluation; instead, we are conducting an especially probing and basic sort of evaluative inquiry.”136

\section{Ten Basic Capabilities}

The ten central human capabilities are:

Life: Being able to live a human life of normal length; not dying prematurely, or to live a life that is not reduced to the point of being not worth living. ${ }^{137}$

Bodily Health: Being able to enjoy a good health; to be adequately nourished; to have adequate shelter. ${ }^{138}$

Bodily Integrity: Being able to move freely; freedom from violence, including sexual assault and domestic violence; having opportunities for sexual satisfaction and freedom in matters of reproduction. ${ }^{139}$

Senses, Imagination, and Thought: Being able to use the senses, to imagine, think, and reason -and most importantly to do so in a "truly human" way, a way which is cultivated by proper education. Being able to use imagination and thought to experience and produce works and events of one's own choice whether religious, literary, musical, and so forth. Being able to use one's mind in ways protected by freedom of expression. Being able to have pleasurable experiences and being able to avoid nonbeneficial pain. ${ }^{140}$

Emotions: Being able to have attachments to things and people outside ourselves; to love, to grieve, to experience longing, gratitude, and anger. Not having one's emotional development suppressed by fear and anxiety. ${ }^{141}$

Practical Reason: Being able to form a conception of the good life and to engage in critical evaluation of our plans of life. This entails protection of freedom of thought and religious liberties. ${ }^{142}$

\footnotetext{
135 Supra-note 133, p. 214.

136 Nussbaum, M., 2003. Capabilities as fundamental entitlements: Sen and social justice. Feminist economics, 9(2-3), pp.33-59. p. 41.

${ }^{137}$ Id.

${ }^{138}$ Id.

140 Id.

${ }^{141}$ Id.

142 Id.
} 
Affiliation: Being able to live and socialize with others, to show concern for other human beings; to be able to identify with the situation of another. Protecting this specific capability requires the protection of institutions and freedoms that constitute and nourish such forms of affiliation.

Having the social bases of self-respect and non-humiliation; being treated in a dignified way; the recognition of our equal worth as human beings. This entails provisions of non-discrimination on the basis of race, sex, sexual orientation, ethnicity, caste, religion, national origin. ${ }^{143}$

Other Species: Being able to live with concern for and in relation to animals, plants, and the world of nature. ${ }^{144}$

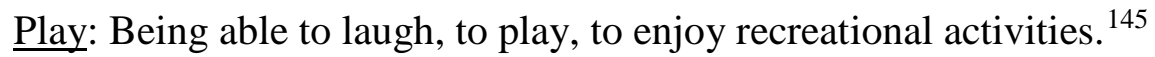

Control over One's Environment: A. Political control: being able to participate effectively in political choices that govern one's life; having the right of political participation, protections of free speech and association. B. Material control: being able to hold property and having property rights on an equal basis with others; having the right to seek employment on an equal basis with others; having the freedom from unwarranted search and seizure. In work, being able to work as a human being, exercising practical reason, and entering into meaningful relationships with other workers. ${ }^{146}$

Nussbaum acknowledges that her list is not exhaustive and needs an ongoing revision and supplementation. Since she is committed to pluralism, the components of Nussbaum's list are deliberately specified in somewhat abstract manner in order to facilitate further deliberations and specification by different constituencies and their democratic institutions. ${ }^{147}$ Nussbaum's list bears resemblance to other scholarly works that inquire into the concept of the human well-being. For example, Finnis identifies seven basic forms of human good that are central for the human well-being, and serve the goal of human flourishing. ${ }^{148}$ According to Finnis the inquiry into the basic aspects of human well-being is an inquiry into human nature. ${ }^{149}$ Finnis assumes that his own inquiry into basic forms of human good parallels the inquiries of anthropologists and psychologists into a possible human nature and its characteristics. ${ }^{150}$ The seven basic forms of goods identified by Finnis

\footnotetext{
${ }^{143} \mathrm{Id}$.

${ }^{144}$ Id.

$145 \mathrm{Id}$.

${ }^{146} \mathrm{Id}$.

${ }^{147} \mathrm{Id}$.

148 John Finnis, supra-note 92.

${ }^{149} \mathrm{Id}$.

${ }^{150} \mathrm{Id}$.
} 
include: life, knowledge, play, aesthetic experience, friendship, practical reasonableness, and religion. ${ }^{151}$ In offering an account of substantive well-being Griffin introduces the following five components: accomplishment, or as he puts it “doing in the course of one's life the sort of things $\ldots$ that give it weight or point; ${ }^{152}$ deep personal relations; ${ }^{153}$ enjoyment; ${ }^{154}$ understanding, which means "knowing about oneself and one's place in the universe"; ${ }^{155}$ and the components of human dignity, which include living as a rational agent and "being able to pursue a course through life chosen by oneself”. 156

\section{Capabilities v. Functionings}

According to Nussbaum, functionings are what render a life fully human. ${ }^{157}$ But since capabilities are preconditions for citizens' freedom to determine their course of action, they should be society's political goal. To illustrate this point, Nussbaum claims that a person who has normal opportunities for sexual satisfaction can freely choose celibacy and that would not pose a moral problem. However, the practice of female genital mutilation, which deprives its victims the opportunity to choose sexual functionings, should worry us due to its impact on future functionings of the victim. ${ }^{158}$

Nussbaum distinguished between three layers of capabilities. The first layer is the basic capabilities; those are "the innate equipment of individuals that is the necessary basis for developing the more advanced capabilities." 159 Certain basic capabilities are ready to function, such as the ability to see or to hear. ${ }^{160}$ But other capabilities, such as imagination and practical reason, cannot be directly converted into functioning; their future exercise depends on other factors such as education and development in other areas. ${ }^{161}$ When basic capabilities are not nourished and transformed into higher-level capabilities, human beings become "fruitless, cut off, in some way but a shadow of themselves". ${ }^{162}$ The second layer is

\footnotetext{
151 Id. at $86-90$.

152 Griffin, J., 2002. A NOTE ON MEASURING WELL-BEING JAMES GRIFFIN. Summary measures of population health: Concepts, ethics, measurement and applications, p.129, 130.

${ }^{153}$ Id.

${ }^{154}$ Id.

155 Id.

156 Id.

157 Supra-note 126, at. 289.

158 Id.

159 Nussbaum, M.C., 2001. Women and human development: The capabilities approach (Vol. 3). Cambridge University Press, p. 84.

${ }^{160} \mathrm{Id}$

${ }^{161}$ Id.

${ }^{162}$ Nussbaum, M., 1995. Human capabilities, female human beings. Women, culture and development: A study of human capabilities, pp.61-104, p. 88.
} 
the internal capabilities; those are "states of the person herself that are, so far as the person herself is concerned, sufficient conditions for the exercise of the requisite functions." 163 Internal capabilities reflect "mature conditions of readiness". ${ }^{164}$ The readiness to exercise certain capabilities requires bodily maturity. For example, sexual functioning requires growing up. Other capabilities require support from and interaction with the surrounding environment for their development, such as the ability to exercise political choice. ${ }^{165}$ At a certain point these capabilities become present, and the individual can use them whenever she wants. For example, most adult human beings have the internal capability to use speech and thought in accordance with their own conscience. ${ }^{166}$ The third layer is the combined capabilities, which are "internal capabilities combined with suitable external conditions for the exercise of the function." ${ }^{167}$ Nussbaum emphasizes that exercising capabilities does not only entail developing basic ones, it also entails "preparing the environment so that it is favorable for the exercise of practical reason and the other major functions". ${ }^{168}$ For example, citizens of oppressive regimes have internal capabilities of freedom of speech, but they lack the combined capability to exercise political freedom of speech. ${ }^{169}$ The aim of public policy should be the production of combined capabilities. States need to provide the necessary education and care, and they need to foster an environment that it is favorable for the exercise of major functions.

\section{Inhuman Treatment Framed Within the Framework of Capabilities}

Capabilities and human rights in general are intimately related. The language of capabilities can provide more precision and supplement the abstract language of rights. Nussbaum claims that "difficult theoretical questions are frequently obscured by the use of rights language, which can give the illusion of agreement where there is deep philosophical disagreement." ${ }^{170}$ Therefore, a different language has emerged for articulating people's basic entitlements such as the language of capabilities. ${ }^{171}$ If inhuman treatment means a treatment which disables the victim to perform basic human functioning, the list articulated by Nussbaum provides a promising guidance. ${ }^{172}$ Unlike the arbitrary fashion in which subsidiary rules were adopted by human rights institutions, Nussbaum's list is theoretically solid, and it is derived from a particular understanding of the notion of a dignified life. It should be noted

\footnotetext{
${ }^{163}$ Supra-note 158, at 84.

164 Id.

${ }^{165}$ Id.

${ }^{166}$ Id.

167 Id.

${ }^{168}$ Id.

${ }^{169} \mathrm{Id}$, at 85.

170 Supra-note 136, at 37.

171 Supra-note 126, at. 275.

172 Supra-note 10.
} 
that the examples provided by Waldron, such as: rational thought, care of self, ability to speak and converse and so forth resonate with Nussbaum's list of basic capabilities. ${ }^{173}$

In what way does inhuman treatment harm human capabilities? Deprivation of liberty inherently reduces the combined capabilities of inmates. The limited contact with the outside world and the limited freedom of movement available to inmates constitute a serious obstacle in exercising certain internal capabilities. However, the prohibition on inhuman treatment is not meant to capture acceptable harms inherent in lawful deprivation of liberty. Inhuman treatment must capture objectionable and serious forms of harm inflicted on the human person. Nussbaum argues that “even a highly trained capability can be thwarted”. ${ }^{174}$ Material and social factors play a twofold role in shaping capabilities: First, they train internal capabilities, and second they allow internal capabilities to express themselves once they are trained. ${ }^{175}$ A change in material and social conditions could have a negative impact both on training and expressing capabilities. Nussbaum emphasizes that it is not always easy to distinguish between harming a combined capability and harming an internal one. ${ }^{176}$ To help us draw the distinction, she suggests that an abrupt change in material and social environment usually reduces combined capabilities; however, "persistent deprivation affects the internal readiness to function". ${ }^{177}$ The prohibition on inhuman treatment should capture the latter situation in which environmental factors cause regression in internal capabilities.

Another distinction articulated by Nussbaum helps linking regression in internal capabilities with the concept of inhuman treatment. Nussbaum distinguishes between two thresholds of capability to function. The first threshold marks the line of capability to function beneath which a human life becomes so impoverished to the point it no longer merits to be labeled "human". ${ }^{178}$ This includes human beings who live in a permanent vegetative condition, and situations where the individual losses the capacity to recognize loved ones, to think and to reason. It could also include a severe absence of mobility that impairs speech and movement. ${ }^{179}$ A second threshold is somewhat higher, beneath which we do recognize the existence of a human life, but we would not judge it as a good life in the Aristotelian sense because the human functions are still reduced ${ }^{180}$

Applying these nuanced differences to the term inhuman treatment, the latter should capture situations where the regression in the internal capabilities, due to human induced conditions, bring the person closer to the first threshold. Cassese, a vocal critic of the practice

\footnotetext{
${ }^{173} \mathrm{Id}$, see also supra-note 136 .

${ }^{174}$ Supra-note 158 , at 84.

${ }^{175}$ Id, at 86 .

${ }^{176}$ Id.

${ }^{177} \mathrm{Id}$

178 Id.

${ }^{179}$ Id.

${ }^{180}$ Id.
} 
of prolonged solitary confinement, used the language of capabilities to articulate the harms associated with this practice:

We could now hear a constant hiss, produced by the air conditioner . . . Apart from the hiss, there was absolutely no other noise ... The murderer was kept in total acoustic isolation... one might have been buried in a tomb ... We asked him if he ever spoke to anyone... [the prisoner was allowed] half an hour's "airing” a day, in a kind of metal cage in the open air, where he could walk up and down, all on his own... The prisoner never saw his relations... He had spent five or six years in that cell, ruminating his unhappy thoughts and had no idea whether he would be there for life. He had not yet passed over from the animal to the vegetable kingdom, but we got an idea of his future condition on entering another cell, where the prisoner. . . had been kept for seven years. He lay on his bed, as pale as a ghost, moaning incomprehensible words. The only thing we understood was a faint "no" when we asked if we were disturbing him and if he preferred to be left alone. He started and trembled at the slightest noise, however imperceptible, which we made while we stayed in the cell. ${ }^{181}$

Cassese talked about the "gradual diminishment" of humanity, and of "state of larvae, where the self is expressed in repetitive physical gestures, until what little, or great, humanity the prisoner possessed... perishes slowly until it disappears completely”. ${ }^{182}$ Not only this language describes the reduction of the internal capabilities, it also depicts a person being pushed closer to the first threshold of capabilities.

One question remains unanswered: Is “intent” a mandatory definitional element of the prohibition on inhuman treatment? In inhuman treatment the primary focus is on the ability of the person to exercise basic human functionings. If the living conditions imposed on a detainee diminish her internal capabilities and bring her close to the first threshold, the lack of intent to cause such damage is immaterial. Inhuman treatment understood as destruction or reduction of internal human capabilities captures a sort of damage to the human person that is of an accumulative nature. When applied to the context of deprivation of liberty, people do not lose their ability to reason, to converse, and so forth in one strike; usually, this sort of damage occurs gradually over time even if there is no intentional policy to cause such damage. Therefore, the intention (or lack-of) of those responsible for the imposition of such conditions is less relevant. The exclusion of intent from the definition of "inhuman treatment" is also consistent with the spirit of human rights law. Unlike

181 Cassese, A., 1996. Inhuman states: Imprisonment, detention and torture in Europe today. Blackwell Publishing, p. 56-57.

182 Id, at 55. 
international criminal law, which focuses on individual criminal responsibility, ${ }^{183}$ human rights law focuses primarily on the legal obligation of States to respect, protect and promote human rights. ${ }^{184}$ Generally speaking, international human rights law does not focus on the intentions and the motives of state agents who violate international law obligations of States. Only when the prohibition is invoked in the realm of international criminal law, intention becomes central for its application.

\section{CONCLUSION}

The aim of this article is to criticize the jurisprudence of supra-national institutions for its failure to define the prohibition on "inhuman treatment." The article argues in its first part that the reluctance of supra-national institutions to provide a conceptually independent definition for inhuman treatment has impoverished the latter's conceptual richness and moral authority. In its second part, the article attempts to regain the conceptual independence of the term by suggesting a definition that makes inhuman treatment clearly distinguishable from its other kin prohibitions. To reconstruct the meaning of the term "inhuman", the article introduces the "capability approach" and the notion of human functioning as keys for rediscovering the essence of the prohibition. Nussbaum's capabilities approach, in particular, provides a solid theoretical framework that gives more precision to the term inhuman, without stripping it from its evaluative nature. Finally, the article suggests defining the term "inhuman treatment" as a treatment that diminishes or reduces the internal capabilities of the human person.

\footnotetext{
${ }^{183}$ For example, According to Article 30 of the Rome Statute a person shall be criminally liable of a crime only if its material elements are committed with intent and knowledge.

184 The UN Human Rights Committee. General Comment No. 31 “The Nature of the General Legal Obligation Imposed on States Parties to the Covenant” (29/3/2004). UN Doc. CCPR/C/21/Rev.1/Add. 1326, see also Waldron, supra-note 74.
} 